\title{
Bilateral sporadic aniridia: review of management
}

This article was published in the following Dove Press journal:

Clinical Ophthalmology

23 September 2010

Number of times this article has been viewed

\author{
Caroline O Adeoti' \\ Adeyinka A Afolabi ${ }^{2}$ \\ Adebimpe O Ashaye ${ }^{3}$ \\ Adenike O Adeoye ${ }^{4}$ \\ 'Department of Ophthalmology, \\ ${ }^{2}$ Department of Paediatrics, Ladoke \\ Akintola University of Technology \\ (LAUTECH) Teaching Hospital, \\ Osogbo, Osun State, Nigeria; \\ ${ }^{3}$ University College Hospital, Ibadan, \\ Oyo State, Nigeria; ${ }^{4}$ Obafemi \\ Awolowo University Teaching \\ Hospital, Ile Ife, Osun, Osun State, \\ Nigeria
}

Purpose: To report a rare case of bilateral sporadic aniridia in an African child and review the management modalities.

Presentation: We report a case of bilateral sporadic aniridia with horizontal nystagmus, axial cataract optic disc, and fovea hypoplasia in a 5-year-old female patient. She was managed conservatively. Various modalities of treatment are reviewed.

Keywords: aniridia, sporadic, nystagmus, cataract, glaucoma, keratopathy, tattooing, syndrome, fovea hypoplasia and optic disc hypoplasia

\section{Introduction}

Aniridia may be congenital or traumatic. Post-traumatic aniridia has been reported following a domestic accident in which total desinsertion of the iris occurred after a contusive trauma associated with the rupture of the eye globe. ${ }^{1}$

In congenital cases, the term aniridia is a misnomer as a rudimentary iris is usually present peripherally. It is often difficult to manage. It is not as common as other congenital eye diseases such as buphthalmos and cataract., ${ }^{2,3}$

It has been reported to have an incidence of between 1: 64,000 and 1: 100,000 4,5 and it may occur in isolation or be associated with a number of syndromes such as WAGR (Wilm's tumor, bilateral sporadic aniridia, genitourinary abnormalities and mental retardation). ${ }^{4}$ It is even rarer in Africa. Two thirds of all cases are familial, and one third is sporadic. ${ }^{6}$ Aniridia occurs as a result of mutations in paired box gene 6 (PAX6) on band p13 of chromosome 11 though there are few reported cases with no identified mutation of PAX6. ${ }^{7}$ The PAX6 gene is a developmental ocular gene and mutations result in panocular changes.

These changes include alterations in corneal cytokeratin expression, cell adhesion and stem-cell deficiency. ${ }^{8}$ It also has a fibrotic nature which may result in failure of many interventions such as penetrating keratoplasty and filtration surgery.

The aim of this report is to highlight the various modalities of management of aniridia and challenges of management in a developing country.

\section{Presentation}

A 5-year-old female presented at our clinic. Her mother complained that her daughter was unable to see well, saw white specks and always walked with her chin lowered in a head-down position since birth. She was delivered by spontaneous vaginal delivery after an uneventful pregnancy. A twin sister died at birth. Nutrition was exclusively
Correspondence: Caroline O Adeoti PO Box 979, Osogbo, Nigeria Email caroladeoti200I@yahoo.co.uk 
breast milk until the patient was 6 months old when she was introduced to other food and artificial milk. Her developmental history was within normal limits. There was no history suggestive of a similar problem in her family.

Her head was tilted down in an attempt to shy away from light. Examination of both eyes revealed a visual acuity of count fingers. Figure 1 shows the right eye of the patient. There was pendulous horizontal nystagmus, clear cornea, rudimentary irises, axial lens opacities, hypoplastic optic discs and fovea hypoplasia. The intraocular pressure with Perkin's tonometer was $16 \mathrm{mmHg}$ and $18 \mathrm{mmHg}$ in right and left eyes respectively.

Pediatric assessment did not reveal any other abnormality. Urinalysis was normal. Abdominal ultrasonography revealed that the liver and spleen were within normal limits; both kidneys had normal sonographic appearance and were normal in size and position, measuring $78 \mathrm{~mm}$ by $32 \mathrm{~mm}$ and $82 \mathrm{~mm}$ by $31 \mathrm{~mm}$ on the right and left respectively. There was no intra-abdominal mass.

She was placed on lubricant gel, oculenta chloramphenicol nocte and advised to rest in dark shade.

\section{Discussion}

Aniridia is a complex disorder that usually results in impaired vision from multiple causes including aniridia associated keratitis (AAK), cataract, glaucoma, foveal hypoplasia, nystagmus and retinal detachment. It is associated with a number of syndromes, including WAGR. Treatment is usually ineffective despite the understanding of the genetics and pathology of the condition. The high rate of failure of surgical intervention is caused by the condition's profibrotic nature. In developing countries, nonavailability of material and human resources necessary for the management of the

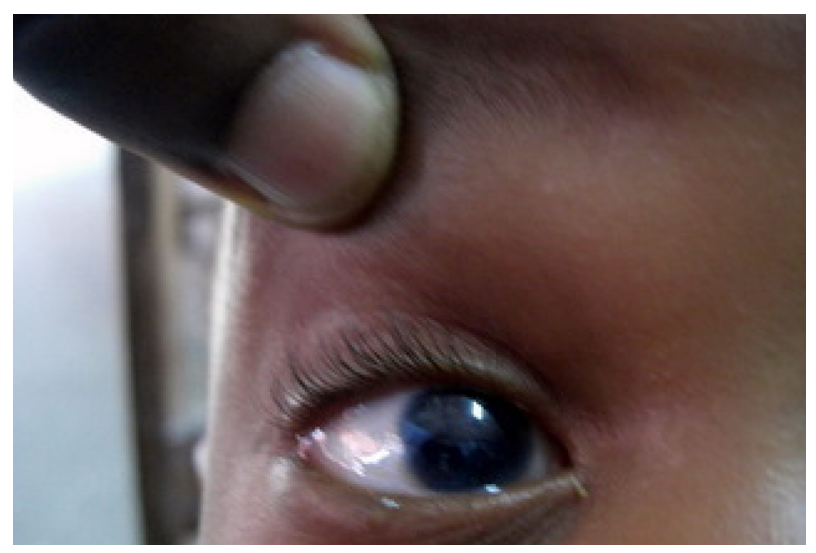

Figure I Shows the right eye of the patient with rudimentary iris, large pupillary space and cataract. cases and poverty especially of the patient in this report worsen the picture. The patient could not afford the necessary investigations such as fundus photography, optical coherence tomography, let alone any treatment.

\section{Management of aniridia}

Aniridia is better managed if the pathology is well understood. Aniridia occurs as a result of mutations in PAX6 on band p13 of chromosome 11 . These mutations cause abnormalities in many parts of the eye. However, there are few reported cases with no identified mutation of PAX6. ${ }^{7}$

PAX6 mutations result in alterations in corneal cytokeratin expression, cell adhesion, and stem-cell deficiency. ${ }^{8}$ These result in a fragile cornea and aniridia-associated keratopathy (AAK). Abnormal differentiation of the angle or progressive angle closure from synechia usually results in glaucoma. Cataract development with associated fragile lens capsule may also be found. The iris is deficient. The optic nerve and fovea are often hypoplastic, and the retina may be prone to detachment. Many interventions including penetrating keratoplasty and filtration surgery usually fail because of the fibrotic nature of this disease.

\section{Aniridia-associated keratopathy}

PAX6 plays a crucial role in the development of the cornea. It regulates the expression of cytokeratins 3 and 12 which form the intermediate filament proteins of the corneal epithelial cells. ${ }^{9}$ These cytokeratins perform a vital role in cell-to-cell binding or adhesion, and in anchoring cells to the underlying basal lamina. In aniridia, there is a decreased expression of the adhesion molecules: desmogleine, $\beta$-catenin, and $\gamma$-catenin. This gives rise to spaces between the corneal epithelial cells. ${ }^{10}$ There is also a deficit in the cell surface glycoconjugate signature in the cornea ${ }^{11}$ resulting in a reduction of the ability of cells to migrate in wound healing. This loss of cytokeratins and cell adhesion, coupled with glycoconjugate defects, result in an extremely fragile corneal surface that is susceptible to recurrent erosions and ulcerations thereby causing AAK which occurs in $20 \%$ of cases. Limbal stem-cell deficiency has also been implicated in AAK. ${ }^{12}$ AAK contributes significantly to the visual loss in aniridia. The clinical features usually appear in the first decade of life. Thickening and vascularization start from the corneal periphery and later advance into the central cornea. AAK is often worse after surgery that interferes with the limbal stem cells or after the use of topical antimetabolites to treat aniridia-associated glaucoma. ${ }^{4} \mathrm{AAK}$ is therefore caused by a combination of factors: Limbal stem-cell deficiency, 
abnormally differentiated epithelium, abnormal cell adhesion and impaired healing response. The symptoms of AAK include photophobia, dry eye, red eye, and epiphora. The patient reported has always had her head tilted down since birth because of photophobia. There is meibomian gland dysfunction and an abnormal tear film, with reduced tear break-up time and reduced tear meniscus. ${ }^{13}$

\section{Management}

This includes the use of preservative-free lubricants and dark glasses for photophobia in the early stages. In moderate keratopathy, serum drops and amniotic membrane transplants may be used. This will facilitate the survival and expansion of surviving limbal stem cells. ${ }^{14}$ Autologous serum eye drops has been found to improve the keratopathy in patients with mild or moderate severity. In these patients, autologous serum eye drops was found to be superior to conventional therapy with artificial tears for improving the ocular surface and subjective comfort. ${ }^{15}$

In severe cases, limbal stem cell transplantation is necessary. ${ }^{16}$ The prognosis of penetrating keratoplasty is poor because of the frequent recurrence of the same pre-graft corneal changes, followed by subsequent graft failure. ${ }^{17,18}$ This is most likely caused by the primary abnormality in the limbal stem cells of the recipient cornea. On the other hand, homologous lamellar limbo-keratoplasty appears to be quite effective in AAK. ${ }^{19,20}$ Its success rate is increased by the use of systemic immunosuppressants compared to using topical immunosuppressants alone. Boston keratoprosthesis is a new approach to managing AAK. ${ }^{21}$ This may reduce the incidence of recurrent graft rejections in AAK.

\section{Glaucoma}

Glaucoma in aniridia, usually occurs during the preadolescent or early adolescent years. ${ }^{22}$ It is thought to be due to developmental abnormalities in the drainage angle of the eye, which obstruct the outflow of aqueous humor.

Grant and Walton ${ }^{23}$ have found that the stroma of the iris extends forwards onto the trabecular meshwork (TM) in the form of synechia-like attachments in the early stages, which later become a homogenous sheet, resulting in eventual angle closure. The diagnosis is made by examination of the angle for evidence of closure, intraocular pressure (IOP) measurement, optic nerve examination, and visual field assessment in an older child. Measurement of central corneal thickness is also important because this has a large impact on the accuracy of tonometric readings. Aniridic patients may have cornea up to $100 \mu \mathrm{m}$ thicker than the average $\mathrm{e}^{24,25}$ making tonometry unreliable in these patients. The treatment of glaucoma associated with aniridia is difficult. Grant and Walton ${ }^{23}$ found that $38.7 \%$ responded to medical treatment, including miotic eye drops. Of those that were responsive to medical treatment, $50.0 \%$ required oral carbonic anhydrase inhibitors. Unsatisfactory results have been reported with cases treated with argon laser trabeculoplasty (ALT) ${ }^{26}$ Diode laser photocoagulation is also ineffective. ${ }^{27}$ Surgical treatment like medical treatment is challenging and includes trabeculectomy $+/-$ antimetabolites, prophylactic goniotomy, therapeutic goniotomy, cyclocryotherapy and guarded filtration surgery. Prophylactic goniotomy has been found to be quite effective in the prevention of glaucoma in patients with aniridia. ${ }^{28}$ The aim is to separate the abnormal extensions of iris stroma from the angle wall, thus preventing closure of the angle. Trabeculectomy has been found to be effective in the treatment of aniridic glaucoma. ${ }^{26}$

Cyclocryotherapy is effective in lowering IOP but serious complications which include phthisis bulbi, progressive cataract and loss of vision can follow $\mathrm{it}^{27}$ making it unsuitable for use as a first-line treatment. ${ }^{29}$

Guarded filtration surgery (GFS) using Ahmed Molteno and Baervaldt implants has been found to be very effective in obtaining control in aniridic glaucoma with success rates ranging from $66 \%$ to $100 \%$. GFS may however be associated with complications such as prolonged hypotony, retinal detachment, migration of the tube, erosion of the tube through the conjunctiva and fibrosis of the anterior chamber. ${ }^{30}$

\section{Iris deficiency}

The iris deficiency associated with aniridia leads to disturbance of vision associated with glare and photophobia.

\section{Management}

Several measures have been taken to overcome these symptoms which include eyelid surgery, corneal tattooing, ${ }^{31}$ and implantation of artificial irides. ${ }^{32}$ Artificial iris implants have been found to diminish visual discomfort such as photophobia. ${ }^{33}$ However, glaucoma has been found to be the most important complication after this procedure though implantation of the iris prosthesis in the capsular bag may reduce this complication, but this requires a large capsulorrhexis and presents a surgical challenge.

The use of a black diaphragm intraocular lens (IOL) to correct both congenital and traumatic aniridia has been advocated. ${ }^{19,34,35}$ These lenses include the Morcher aniridia IOL types $67 \mathrm{~F}$ and $67 \mathrm{G}$, the aniridia ring type $50 \mathrm{C}$ and the coloboma diaphragm type $96 \mathrm{G}$. They can be placed in the ciliary sulcus if there is adequate support, or are sutured trans-sclerally. 
Complications reported included postoperative uveitis, secondary glaucoma, clinically significant macular edema (CSMO), chronic endothelial cell loss, progression of corneal epithelial disorders and hyphema. ${ }^{19,34}$

\section{Cataract}

This is a common association with aniridia as found in this report. Nelson et al found cataract in 50\%-85\% of patients with aniridia. ${ }^{22}$ Cataract extraction is often necessary with or without IOL insertion. However, the anterior capsule of aniridia cataracts has been found to be very fragile, ${ }^{36}$ hence, care must be taken during surgery to avoid capsular complications. The use of a black diaphragm IOL consisting of an opaque diaphragm surrounding the transparent optic has recorded satisfactory results. ${ }^{37,38}$

\section{Posterior segment abnormalities}

Optic nerve hypoplasia and macular hypoplasia are common findings and these contribute to visual malfunction in aniridia. ${ }^{22}$ Optic nerve hypoplasia is found in approximately $10 \%$ of cases. ${ }^{39}$ Pendular horizontal nystagmus as found in this report, occurs in most patients, secondary to macular hypoplasia. Aniridia may also be associated with retinal tears and detachments. Retinal detachments occurred in four eyes of three children as a result of giant retinal tears in one study. ${ }^{40}$ These were treated with vitreolensectomy and silicone oil injection with two of the eyes recovering useful vision.

Optical coherence tomography (OCT) has been found to be useful in the diagnosis of foveal hypoplasia in children with aniridia. ${ }^{41}$

Nonavailability of material and human resources necessary for the management of the developments in follow up coupled with poverty of the parents especially of the child in this report who could not afford the various investigations such as fundus photograph and OCT may affect the prognosis in developing countries.

\section{Conclusion}

Aniridia is a complex disorder that involves many parts of the eye and which may result in impaired vision from multiple causes. Understanding the management of the condition and availability of necessary manpower and material needs useful in management will go a long way in assisting the occasional cases that are seen in developing countries.

\section{Disclosure}

The authors report no conflicts of interest in this work.

\section{References}

1. Talu S, Calugaru M. Posttraumatic aniridia - clinical reports. Oftalmologia. 2003;59(4):36-38.

2. Lawan A. Congenital eye and adnexial anomalies in Kano, a five year review. Niger J Med. 2008;17(1):37-39.

3. Bodunde OT, Ajibode HA. Congenital eye diseases at Olabisi Onabanjo University Teaching Hospital, Sagamu, Nigeria. Niger J Med. 2006;15(3):291-294.

4. Nelson LB, Spaeth GL, Nowinski TS, Margo CE, Jackson L. Aniridia. A review. Surv Ophthalmol. 1984;28:621-642.

5. Eden U, Iggman D, Ruse R, Tornqvist K. Epidemiology of aniridia in Sweden and Norway. Acta Ophthalmol. 2008;86(7):727-729.

6. Verloes A, Temple IK, Bonnet S, Bottani A. Coloboma, mental retardation, hypogonadism and obesity: critical review of the so-called Biemond syndrome type 2, updated nosology and delineation of three new syndromes. Am J Med Genet. 1997;69:370-379.

7. Traboulsi EI, Ellison J, Sears J, Maumenee IH, Avallone J, Mohney BG. Aniridia with preserved visual function: a report of four cases with no mutations in Pax6. Am J Ophthalmol. 2008;145:760-764.

8. Lee H, Khan R, O'Keefe M. Aniridia: current pathology and management. Acta Ophthalmol. 2008;86(7);708-715.

9. Ramaesh T, Collinson JM, Ramaesh K, Kaufman MH, West JD, Dhillon B. Corneal abnormalities in Pax6 +/- small eye mice mimic human aniridia-related keratopathy. Invest Ophthalmol Vis Sci. 2003;44:1871-1878.

10. Davis J, Duncan MK, Robison WG Jr, Piatigorsky J. Requirement for Pax6 in corneal morphogenesis: a role in adhesion. J Cell Sci. 2003;116:2157-2167.

11. Kucerova R, Ou J, Lawson D, Leiper LJ, Collinson JM. Cell surface glycoconjugate abnormalities and corneal epithelial wound healing in the pax $6+/-$ mouse model of aniridia-related keratopathy. Invest Ophthalmol Vis Sci. 2006;47:5276-5282.

12. Tseng SC, Li DQ. Comparison of protein kinase C subtype expression between normal and aniridic human ocular surfaces: implications for limbal stem cell dysfunction in aniridia. Cornea. 1996;15:168-178.

13. Jastaneiah S, Al-Rajhi AA. Association of aniridia and dry eyes. Ophthalmology. 2005;112:1535-1540.

14. Lopez-Garcia JS, Garcia-Lozano I, Rivas L, Martinez-Garchitorena J. Congenital aniridia keratopathy treatment. Arch Soc Esp Oftalmol. 2006;81:435-444.

15. Lopez-Garcia JS, Rivas L, Garcia-Lozano I, Murube J. Autologous serum eyedrops in the treatment of aniridic keratopathy. Ophthalmology. 2008;115(2):262-267.

16. Kruse FE, Reinhard T. Limbus transplantation for reconstruction of the ocular surface. Ophthalmologe. 2001;98:818-831.

17. Gomes JA, Eagle RC, Gomes AK, Rapuano CJ, Cohen EJ, Laibson PR. Recurrent keratopathy after penetrating keratoplasty for aniridia. Cornea. 1996; 15:457-462.

18. Kremer I, Rajpal RK, Rapuano CJ, Cohen EJ, Laibson PR. Results of penetrating keratoplasty in aniridia. Am J Ophthalmol. 1993;115:317-320.

19. Sundmacher T, Reinhard T, Althaus C. Black diaphragm intraocular lens in congenital aniridia. Ger J Ophthalmol. 1994;3:197-201.

20. Holland EJ, Djalilian AR, Schwartz GS. Management of aniridic keratopathy with keratolimbal allograft: a limbal stem cell transplantation technique. Ophthalmology. 2003;110:125-130.

21. Akpek EK, Harissi-Dagher M, Petrarca R, et al. Outcomes of Boston keratoprosthesis in aniridia: a retrospective multicenter study. $\mathrm{Am} \mathrm{J}$ Ophthalmol. 2007;144:227-231.

22. Nelson LB, Spaeth GL, Nowinski TS, Margo CE, Jackson L. Aniridia. A review. Surv Ophthalmol. 1984;28:621-642.

23. Grant WM, Walton DS. Progressive changes in the angle in congenital aniridia, with development of glaucoma. Trans Am Ophthalmol Soc. 1974;72:207-228

24. Brandt JD, Casuso LA, Budenz DL. Markedly increased central corneal thickness: an unrecognized finding in congenital aniridia. $\mathrm{Am} \mathrm{J}$ Ophthalmol. 2004;137:348-350. 
25. Whitson JT, Liang C, Godfrey DG, et al. Central corneal thickness in patients with congenital aniridia. Eye Contact Lens. 2005;31:221-224

26. Wiggins RE, Tomey KF. The results of glaucoma surgery in aniridia. Arch Ophthalmol. 1992;110:503-505.

27. Wallace DK, Plager DA, Snyder SK, Raiesdana A, Helveston EM, Ellis FD. Surgical results of secondary glaucomas in childhood. Ophthalmology. 1998;105:101-111.

28. Chen TC, Walton DS. Goniosurgery for prevention of aniridic glaucoma. Trans Am Ophthalmol Soc. 1998;96:155-165.

29. Wagle NS, Freedman SF, Buckley EG, Davis JS, Biglan AW. Longterm outcome of cyclocryotherapy for refractory pediatric glaucoma. Ophthalmology. 1998;105:1921-1926.

30. Munoz M, Tomey KF, Traverso C, Day SH, Senft SH. Clinical experience with the Molteno implant in advanced infantile glaucoma. J Pediatr Ophthalmol Strabismus. 1991;28:68-72.

31. Beekhuis WH, Drost BH, van der Velden Samderubun EM. A new treatment for photophobia in posttraumatic aniridia: a case report. Cornea. 1998;17(3):338-341.

32. Burris TE, Holmes-Higgin DK, Silvestrini TA. Lamellar intrastromal corneal tattoo for treating iris defects (artificial iris). Cornea. 1998;17:169-173.

33. Menezo JL, Martinez-Costa R, Cisneros A, Desco MC. Implantation of iris devices in congenital and traumatic aniridias: surgery solutions and complications. Eur J Ophthalmol. 2005;15(4):451-457.
34. Reinhard T, Engelhardt S, Sundmacher R. Black diaphragm aniridia intraocular lens for congenital aniridia: long-term follow-up. J Cataract Refract Surg. 2000;26:375-381.

35. Burk SE, Da Mata AP, Snyder ME, Cionni RJ, Cohen JS, Osher RH. Prosthetic iris implantation for congenital, traumatic, or functional iris deficiencies. J Cataract Refract Surg. 2001;27:1732-1740.

36. Schneider S, Osher RH, Burk SE, Lutz TB, Montione R. Thinning of the anterior capsule associated with congenital aniridia. J Cataract Refract Surg. 2003;29:523-525.

37. Beltrame G, Salvetat ML, Chizzolini M, et al. Implantation of a black diaphragm intraocular lens in ten cases of post-traumatic aniridia. Eur J Ophthalmol. 2003;13(1):62-68.

38. Chen YJ, Wu PC. Favorable outcome using a black diaphragm intraocular lens for traumatic aniridia with total iridectomy. J Cataract Refract Surg. 2003;29(12):2455-2457.

39. McCulley TJ, Mayer K, Dahr SS, Simpson J, Holland EJ. Aniridia and optic nerve hypoplasia. Eye (Lond). 2005;19:762-764.

40. Dowler JG, Lyons CJ, Cooling RJ. Retinal detachment and giant retinal tears in aniridia. Eye (Lond). 1995;9:268-270.

41. McGuire D, Weinreb R, Goldbaum M. Foveal hypoplasia demonstrated in vivo with optical coherence tomography. Am J Ophthal. 2003;135(1):112-114.
Clinical Ophthalmology

\section{Publish your work in this journal}

Clinical Ophthalmology is an international, peer-reviewed journal covering all subspecialties within ophthalmology. Key topics include: Optometry; Visual science; Pharmacology and drug therapy in eye diseases; Basic Sciences; Primary and Secondary eye care; Patien Safety and Quality of Care Improvements. This journal is indexed on

Submit your manuscript here: http://www.dovepress.com/clinical-ophthalmology-journal

\section{Dovepress}

PubMed Central and CAS, and is the official journal of The Society of Clinical Ophthalmology (SCO). The manuscript management system is completely online and includes a very quick and fair peer-review system, which is all easy to use. Visit http://www.dovepress.com/ testimonials.php to read real quotes from published authors. 